\title{
SUBSTITUTION PROCESSES IN SIMPLE AND COMPLICATED METAL COMPLEXES
}

\author{
R. G. WILKINS \\ Department of Chemistry, State University of New York at Buffalo, \\ Buffalo, New York 14214
}

\begin{abstract}
The mechanisms of substitution in transition metal complexes are reviewed with particular emphasis on recent developments. Strong support is available for a dissociative mechanism in formation reactions, in which the release of water from the metal ion controls the rate of entry of ligand. This generalization breaks down in the case of certain protonated ligands as well as multidentate ligands of special structure.

Some substitution reactions of carbonic anhydrase (in the native and cobalt forms) are reviewed. These include the interaction of enzyme with inhibitors, including sulphonamides and cyanate ion. Kinetic data for these are discussed. The results of studies of the regeneration of the haloenzyme from apoenzyme and metal ion or metal complexes are given and discussed.
\end{abstract}

I had the pleasure of helping Dr. Chatt in the organization of the first I.C.C.C. (although it was not recognized as such at that time). It was held in the I.C.I. Research Laboratories at Welwyn in 1950 and forty people attended from several countries ${ }^{1}$. In writing this lecture, I have reflected on the advances that have been made in the area of the kinetics of substitution in the 20 years or so since that small first gathering. In 1950 the terms labile and inert had not been coined. Detailed studies of substitution in $\mathrm{Co}^{\mathrm{III}}$ and $\mathrm{Pt}^{\mathrm{II}}$ had not been undertaken, and no kinetic study of a labile complex had been reported-indeed, many of the rapid reaction techniques had yet to be developed ${ }^{2}$. Perhaps it was not surprising that not one paper on kinetics was included in the 1950 programme! The basic patterns of substitution are now fairly well understood, although many of the details are still missing.

Replacement of one ligand by another in a complex is an important process which permeates all aspects of coordination chemistry. It plays a role in formation, hydrolysis, polymerization and redox reactions. Catalysis and inhibition in metalloenzyme-promoted reactions and the transport of metal ions through cell membranes also have substitution processes as an important component.

There have been a number of recent accounts of substitution in metal complexes $^{2-8}$ and so I have restricted this lecture to a few topics, governed mainly by personal interests and largely concerned with the behaviour in aqueous solution of labile metal complexes, often those of nickel. Some recent chemistry of replacement reactions of carbonic anhydrase which has 


\section{R. G. WILKINS}

been developing recently will also be included and an attempt will be made to draw parallelisms between the behaviour of these and much simpler systems.

\section{REPLACEMENT OF UNIDENTATE LIGANDS}

It is a reasonable truth that the rate constants for reaction of a variety of unidentate ligands with $\mathrm{Ni}^{2+}$ can be rationalized in terms of a dissociative mechanism ${ }^{6}$. In this mechanism, the entering ligand plays a minor role and water loss from the coordination sphere of the metal is the paramount act. This situation can be accommodated in terms of the Eigen mechanism, although this is not a unique explanation. In this, rate-determining $\mathrm{H}_{2} \mathrm{O}-\mathrm{L}^{\mathrm{n}}$ interchange occurs within a very rapidly formed outer-sphere complex, leading to an inner-sphere complex :

$$
\begin{aligned}
& \mathrm{Ni}\left(\mathrm{H}_{2} \mathrm{O}\right)_{6}^{2+}+\mathrm{L}^{\mathrm{n}-} \rightleftarrows\left(\mathrm{H}_{2} \mathrm{O}\right)_{5} \mathrm{Ni}\left(\mathrm{H}_{2} \mathrm{O}\right) \mathrm{L}^{(2-\mathrm{n})+} K_{0} \\
& \left(\mathrm{H}_{2} \mathrm{O}\right)_{5} \mathrm{Ni}\left(\mathrm{H}_{2} \mathrm{O}\right) \mathrm{L}^{(2-\mathrm{n})+} \rightleftarrows\left(\mathrm{H}_{2} \mathrm{O}\right)_{5} \mathrm{NiL}^{(2-\mathrm{n})+}+\mathrm{H}_{2} \mathrm{O} \quad k_{0}
\end{aligned}
$$

A number, but not all, of the observations of metal complexation can be rationalized in terms of this scheme. For example, by combining the secondorder rate constants $(k)$ in Table $1^{6,8}$ with estimated values for $K_{0}$, remarkably constant values for $k_{0}$ are obtained from the relationship governing

Table 1. Rate constants for the formation of nickel(n) complexes with unidentate ligands at $25^{\circ} \mathrm{C}$

\begin{tabular}{lcc}
\hline \multicolumn{1}{c}{$\mathrm{L}^{\mathrm{n}-}$} & $\begin{array}{c}10^{-3} k \\
\left(\mathrm{M}^{-1} \mathrm{~s}^{-1}\right)\end{array}$ & $10^{-4} k_{0}$ \\
\hline $\mathrm{CH}_{3} \mathrm{PO}_{4}^{2-}$ & 290 & 0.7 \\
$\mathrm{CH}_{3} \mathrm{COO}^{-}$ & 100 & 3 \\
$\mathrm{HF}$ & 3 & 2 \\
$\mathrm{NH}_{3}$ & 5 & 3 \\
$\left(\mathrm{CH}_{3}\right)_{2} \mathrm{NH}$ & 0.33 & - \\
$\mathrm{NH}_{2}\left(\mathrm{CH}_{2}\right)_{2} \mathrm{~N}\left(\mathrm{CH}_{3}\right)_{3}^{+}$ & 0.4 & 2 \\
\hline
\end{tabular}

the above mechanism, i.e. $k=K_{0} k_{0}$. The constancy of $k_{0}$ is understandable if, in the second step, the dissociation of water is only slightly dependent on the nature of $\mathrm{L}$. The decrease in the value of $k$ with increased alkyl substitution in $\mathrm{NH}_{3}$, see Table $1^{8}$, probably reflects a decreased value of $K_{0}$ for the alkylamine as a result of steric hindrance. The results re-emphasize the problem in assessing $K_{0}$ values, and thereby understanding $k$ values, particularly for neutral ligands ${ }^{9}$.

A fair amount of work has gone into the attempted characterization of the five-coordinated intermediate in substitution reactions of inert complexes ${ }^{2}$. In certain cases, almost definitive answers have been obtained. Nothing is known, however, about the shape of this intermediate in reactions of the labile ions. The similar rate constant for exchange of solvent water with (I) $\left(3.8 \times 10^{4}\right)$ as with $\mathrm{Ni}\left(\mathrm{H}_{2} \mathrm{O}\right)_{6}^{2+}\left(3.2 \times 10^{4} \mathrm{~s}^{-1}\right)$ does suggest that there are no large changes in geometry in the formation of the transition state, which is therefore probably square pyramidal. The fused ring in (I) would discourage 
radical changes in geometry ${ }^{10}$. These $\mathrm{H}_{2} \mathrm{O}$ exchange data have been obtained by n.m.r. line broadening, a technique which has found a unique niche in the study of ligand lability ${ }^{11,12}$. The relatively mild effect of the ligand in (I) on

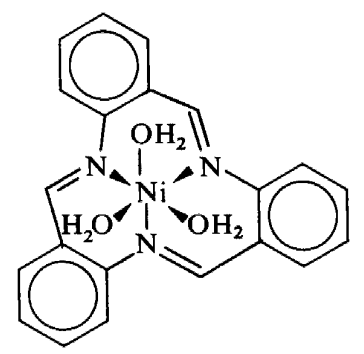

(I)

the water exchange rate is paralleled by a number of similar type complexes containing Schiff bases, including the tetragonally distorted nickel(II) complex of (II) ${ }^{13}$. Such a situation does not prevail, however, when a metal<smiles>CC1CCCN=Cc2cccc(n2)C=NCCCN1C</smiles>

(II)

ion is coordinated by a planar porphyrin-type ligand. The remaining axial positions are labilized even for the normally inert $\mathrm{Cr}^{\mathrm{III14}}, \mathrm{Co}^{\mathrm{III15}}$ and $\mathrm{Ru}^{\mathrm{II} 16}$ complexes. It would have been interesting to have examined ligand substitution at the $\mathrm{Ni}$ (tetrasulphophthalocyanine) ${ }^{2-}$ centre but there is no sign of axial interaction by imidazole or $\mathrm{CN}^{-}$ion, emphasizing the strong ligand field of the cyclic ligand ${ }^{17}$. However, the rate of the very rapid ${ }^{18}$ interconversion:

$$
\begin{aligned}
& \mathrm{Ni}(2,3,2-\text { tet })\left(\mathrm{H}_{2} \mathrm{O}\right)_{2}^{2+} \rightleftarrows \mathrm{Ni}(2,3,2 \text {-tet })^{2+}+2 \mathrm{H}_{2} \mathrm{O} \\
& \text { blue, octahedral yellow, square planar }
\end{aligned}
$$

where 2,3,2-tet $=\mathrm{H}_{2} \mathrm{~N}\left(\mathrm{CH}_{2}\right)_{2} \mathrm{NH}\left(\mathrm{CH}_{2}\right)_{3} \mathrm{NH}\left(\mathrm{CH}_{2}\right)_{2} \mathrm{NH}_{2}$, has been measured by a relaxation method in which the concentration of the planar species is enhanced by a $30 \mathrm{~ns} 1.06 \mu \mathrm{m}$ pulse, and the return to the normal concentration after the pulse is monitored spectrally. If the suggested mechanism

$$
\begin{aligned}
& \mathrm{Ni}(2,3,2 \text {-tet })\left(\mathrm{H}_{2} \mathrm{O}\right)_{2}^{2+} \rightleftarrows \mathrm{Ni}(2,3,2 \text {-tet })\left(\mathrm{H}_{2} \mathrm{O}\right)^{2+}+\mathrm{H}_{2} \mathrm{O} \quad k_{1}, k_{-1} \\
& \mathrm{Ni}(2,3,2 \text {-tet })\left(\mathrm{H}_{2} \mathrm{O}\right)^{2+} \rightleftarrows \mathrm{Ni}(2,3,2 \text {-tet })^{2+}+\mathrm{H}_{2} \mathrm{O} \quad k_{2}, k_{-2}
\end{aligned}
$$

is correct, the derived value for $k_{-2}$ is $5.6 \times 10^{4} \mathrm{M}^{-1} \mathrm{~s}^{-1} 19$.

One final recent example of interest concerns the complex of $\mathrm{Ni}^{\text {II }}$ with tren (III). Two rate constants $\left(9 \times 10^{6}\right.$ and $\left.8 \times 10^{5} \mathrm{~s}^{-1}\right)$ for exchange of solvent 


\section{R. G. WILKINS}

water with coordinated water have been measured by $n \cdot m \cdot r^{20}$. This observation sheds some light on some anomalously low rate constants for interaction of $\mathrm{Ni}$ (tren) $\left(\mathrm{H}_{2} \mathrm{O}\right)_{2}^{2+}$ with phenanthroline ${ }^{6}$.

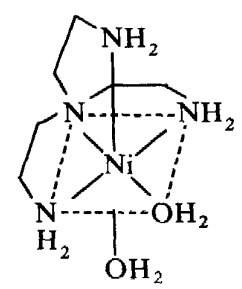

(III)

\section{EFFECT OF PROTONATION OF THE ENTERING LIGAND}

There are a number of ways in which a proton attached to a ligand can affect the rate of metal complexing.

The protonated form of a unidentate ligand is often unreactive, since protonation removes a lone pair and the ability to coordinate. Thus $\mathrm{NH}_{4}^{+}$, $\mathrm{RNH}_{3}^{+9}$, pyH ${ }^{+}$(Ref. 21, 22), $\mathrm{HOCN}^{23}$ and possibly imidH ${ }^{+}$(which in principle might retain some nucleophilic character) ${ }^{24,25}$ have all been shown to be unreactive towards a number of metal ions. In a number of cases the protonated unidentate ligand retains some reactivity, although much less than that of the conjugate base. Rate constants for reaction of $\mathrm{HCN}^{26}$, $\mathrm{HONO}^{27}, \mathrm{~N}_{2} \mathrm{H}_{5}^{+}{ }^{21}, \mathrm{HF}^{28}$ and $\mathrm{HN}_{3}{ }^{23,29}$ with various metal complexes have been measured. If the proton is far removed from the reaction site, it has little effect. The rate constants for reaction of 4-cyanopyridine and 4-cyanopyridinium ion with $\mathrm{Ru}\left(\mathrm{NH}_{3}\right)_{5} \mathrm{H}_{2} \mathrm{O}^{2+}$ are 0.26 and $0.24 \mathrm{M}^{-1} \mathrm{~s}^{-1}$, respectively $\left(25^{\circ} \mathrm{C}, 50\right.$ per cent aqueous methanol). Here coordination of the cyano group is involved. With coordination of pyridine, however, $(k=$ $\left.0.05 \mathrm{M}^{-1} \mathrm{~S}^{-1}\right)$ there is no reactivity associated with the protonated form ${ }^{22}$.

Table 2. Rate constants for reaction with $\mathrm{Ni}^{2+}$ at $25^{\circ} \mathrm{C}$

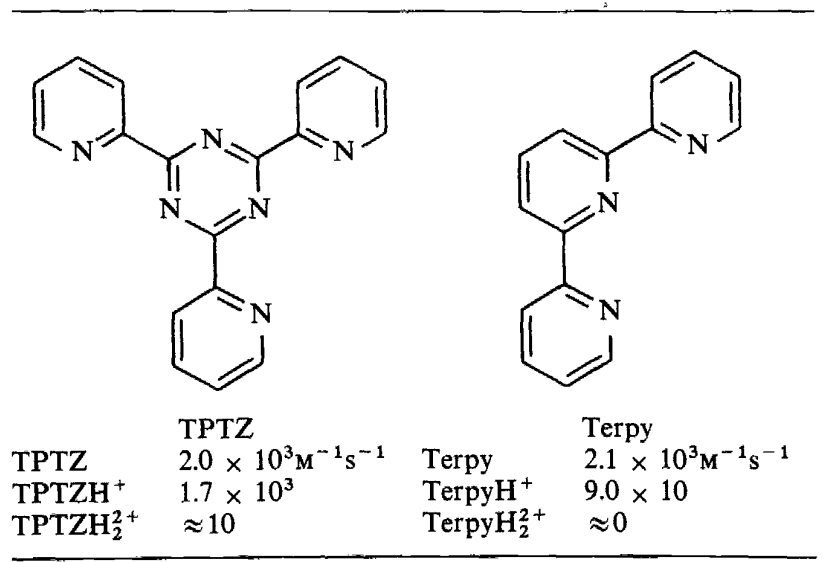


Much larger effects of protonation on the rates of chelation by multidentate ligands would be expected, and are observed. Once again, if the proton is far removed from a potential reaction site, as in $\mathrm{TPTZH}^{+}$, it only slightly modifies the rate (compare terpyH ${ }^{+}$, a formally analogous ligand) $(\text { Table } 2)^{25,30}$. Often the role of the proton may be solely one of increasing the positive charge and since most reactions are with cationic complexes, this will lead to a decreased outer-sphere association constant, and decreased overall rate constant. Additionally, each proton added to a multidentate ligand reduces the number of available sites for attack on the metal.

The proton may play a much more significant role by blocking the reaction site as in bipyH ${ }^{+}$and particularly phenH $^{+}$and terpyH ${ }_{2}^{2+}$ (Table 3). A cis

Table 3. Rate constants for reaction of $\mathrm{Ni}^{2+}$ and $\mathrm{Cu}^{2+}$ at $25^{\circ} \mathrm{C}$

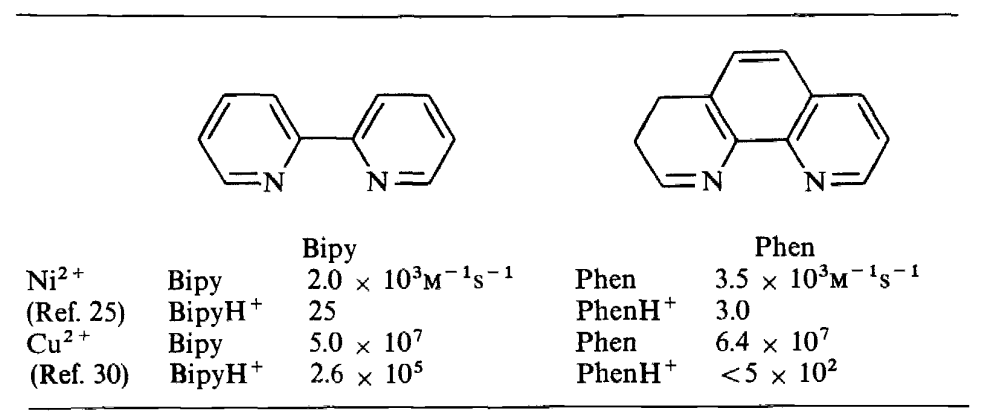

conformation for bipyH ${ }^{+}$with the pyridine rings slightly twisted ${ }^{31}$ allows approach of the nitrogen centre to the metal, much more easily than in phenH ${ }^{+}$where twisting in the cis conformation is not possible. The very small rate constant for reaction of terpyH $\mathrm{H}_{2}^{2+}\left(<0.5 \mathrm{M}^{-1} \mathrm{~s}^{-1}\right)$ probably arises from very unfavourable charge as well as steric hindrance considerations. The two protons in the cis-cis conformation ${ }^{31}$ effectively block the lone free nitrogen.

The non-reactivity of the zwitterionic form of aliphatic amino carboxylates is well documented ${ }^{32}$. It is also observed in the saturated pyridine system, piperidine-2,6-dicarboxylate. However, with the heterocyclic derivative, pyridine-2,6-dicarboxylate, an appreciable value for the rate constant for the protonated form $\left(5 \times 10^{3} \mathrm{M}^{-1} \mathrm{~s}^{-1}\right)$ is obtained. This can be ascribed to about 25 per cent of the non-zwitterion form (V) being present in equilibrium with the zwitterion (IV). For the monocarboxylate derivative the reduced rate constant $\left(\approx 30 \mathrm{M}^{-1} \mathrm{~s}^{-1}\right)$ indicates a smaller amount of the noncharged form ( 2 per cent) and this figure is in agreement with spectral and $\mathrm{pK}_{\mathrm{a}}$ data which indicate approximately 5 per cent present ${ }^{32}$.<smiles>COC(=O)c1cccc(C(=O)O)[nH+]1</smiles>

(IV)<smiles>O=C(O)c1cccc(C(=O)O)n1</smiles>

(V) 


\section{R. G. WILKINS}

Protonation may lead to a radical structural change with the production of an unreactive tautomer. This is exemplified by the behaviour of chelidamic $\operatorname{acid}^{25}$.<smiles>O=C([O-])c1cc(O)cc(C(=O)[O-])n1</smiles>

(VI)<smiles>O=C([O-])c1cc(O)cc(C(=O)[O-])[nH+]1</smiles>

(VII)<smiles>COC(=O)c1cc(=O)cc(C(=O)[O-])[nH]1</smiles>

(VIII)<smiles></smiles>

(IX)<smiles>O=C(O)c1cc(O)cc(C(=O)O)n1</smiles>

(X)

The monoprotonated form exists predominently as the pyridone form (VIII) rather than the tautomer (VI), from considerations of $\mathrm{pK}_{\mathrm{a}}$ and spectra ${ }^{33}$. Form (VIII) would be expected to be quite unreactive, especially since a zwitterion form (IX) would make an important contribution. If a rate constant is assigned to (VI) similar to that for pyridine-2,6-dicarboxylate $\left(6.3 \times 10^{4} \mathrm{M}^{-1} \mathrm{~s}^{-1}\right)$ then the observed rate constant $\left(1.7 \times 10^{2}\right)$ for the tautomeric mixture would be due to 0.3 per cent (VI).

In 4-hydroxypyridine the tautomeric ratio is $2 \times 10^{3}$ in favour of the pyridone form ${ }^{34}$. It is difficult to assess the effect of the adjacent carboxylate group on this ratio ${ }^{34}$, but our value $>4 \times 10^{2}$ appears reasonable. The diprotonated form of chelidamic acid exists as 4-hydroxypyridinium-2,6dicarboxylate (VII). Its reduced reactivity $\left(k=60 \mathrm{M}^{-1} \mathrm{~s}^{-1}\right)$ compared with pyridinium-2,6-dicarboxylate (IV), (V), $k=5.0 \times 10^{3} \mathrm{M}^{-1} \mathrm{~s}^{-1}$ probably arises from a much smaller percentage $(\approx 0.2$ per cent $)$ of the non-zwitterion form (X).

One effect of protonation which tends to show up only with the more labile ions is the incidence of proton loss from a protonated intermediate being rate determining. Consider the simple analysis of the reaction of $\mathrm{Cu}^{\text {II }}$ ion with a protonated polyamine.

$$
\mathrm{Cu}+\mathrm{L}-\mathrm{LH} \underset{k_{-1}}{\stackrel{k_{1}}{\rightleftarrows}} \mathrm{Cu}-\mathrm{L}-\mathrm{LH} \underset{k_{-2}}{\stackrel{k_{2}}{\rightleftarrows}} \mathrm{Cu}-\mathrm{L}-\mathrm{L}+\mathrm{H}^{+} \rightarrow \mathrm{Cu} \overbrace{\mathrm{L}}^{\prime}
$$

If $k_{1}$ and $k_{-1}$ are both large compared with $k_{2}$, and this can be shown to apply to $\mathrm{L}-\mathrm{LH} \equiv \mathrm{enH}^{+}$, then $^{35}$

$$
k_{\text {obsd }}=\frac{k_{1} k_{2}}{k_{-1}} \approx 2 \times 10^{2} \times 5 \times 10^{2} \approx 10^{5}
$$

is in good agreement with the experimental value $\mathrm{e}^{35,36}$ of $1.7 \times 10^{5} \mathrm{M}^{-1} \mathrm{~s}^{-1}$. If, however, $k_{2}>k_{-1}$, which will occur if the $\mathrm{Cu}-\mathrm{L}-\mathrm{LH}$ is fairly strongly acidic, as when $\mathrm{L}-\mathrm{LH} \equiv$ tetraen $\mathrm{H}_{3}^{3+}$, then

$$
k_{\text {obsd }}=k_{1}=1.6 \times 10^{5}{\text { (experimentally })^{37}}^{37}
$$


This point can be made in a different way. Figure 1 shows a $\log$ - $\log$ plot of rate constants for reaction of $\mathrm{Cu}^{2+}$ and $\mathrm{Ni}^{2+}$ with a large variety of ligands of varying size and dentaticity, as well as magnitude and sign of charge ${ }^{38}$. For some 15 ligands the relationship $4.6<\log k_{\mathrm{Cu}} / k_{\mathrm{Ni}}<5.3$ is obeyed.

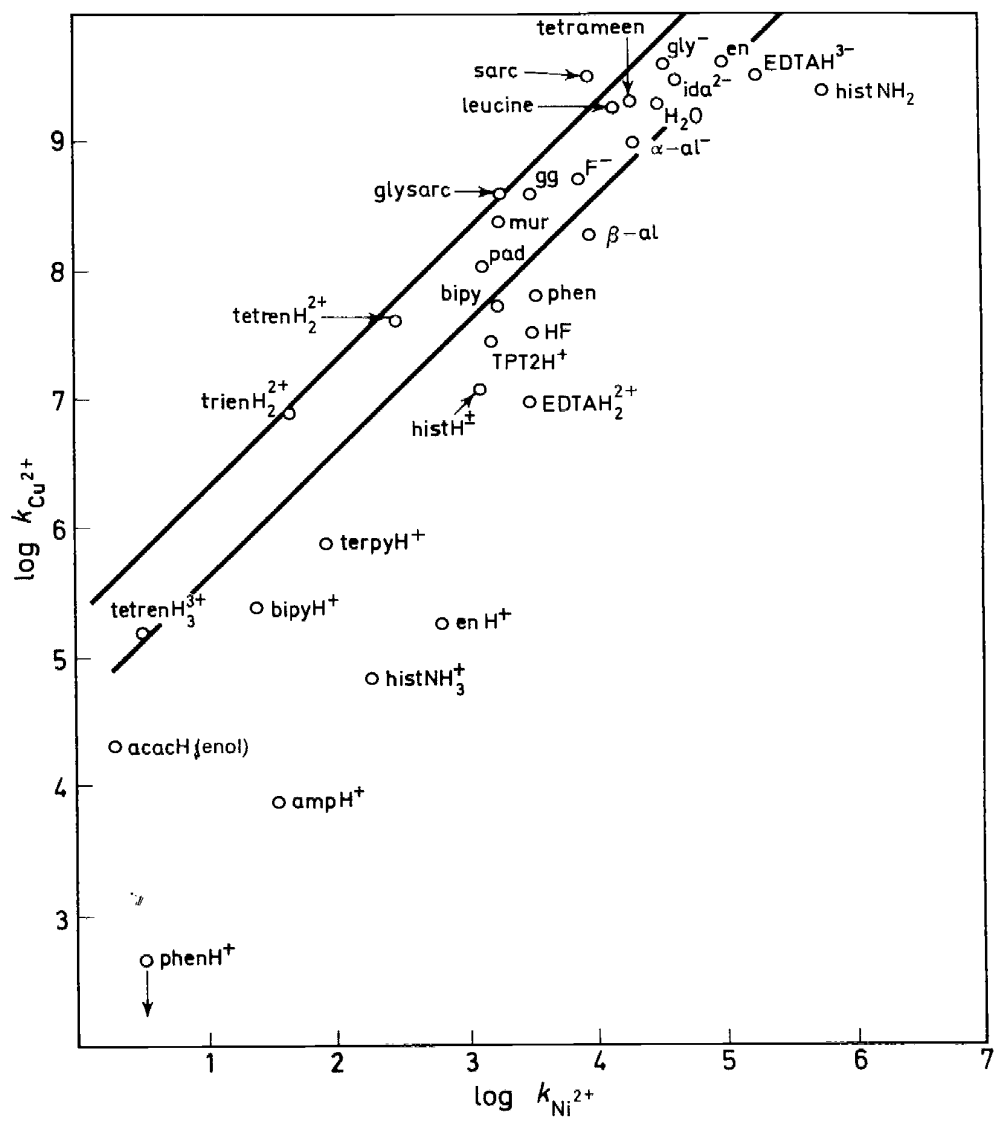

Figure 1. $\mathrm{Log}-\log$ plot of rate constants for $\mathrm{Cu}^{2+}$ and $\mathrm{Ni}^{2+}$ reaction with a large variety of ligands

Those that are not enclosed in this narrow band of rate constant ratios, fall below it and such ligands react anomalously slowly with at least $\mathrm{Cu}^{2+}$ and in certain instances with $\mathrm{Ni}^{2+}$ also. They include a number of the protonated diamines for which analysis of the type above indicated that proton release is an important step in $\mathrm{Cu}^{2+}$ complexing. In addition, it may be noted that tetren $\mathrm{H}_{3}^{3+}$ falls in the 'normal' band. With all these protonated polyamines, the first bond-formation step with $\mathrm{Ni}^{2+}$ is rate determining ${ }^{39}$. Also falling outside the normal band are the protonated bipyridyl type of ligands as well as $\beta$-alanine, which forms a six-membered ring by sterically controlled substitution ${ }^{40}$.

The assignment of a mechanism for complexation of copper has proved very difficult ${ }^{41}$. Often the reactions have been considered to be dissociative 
and the marked lability of $\mathrm{Cu}^{\mathrm{II}}$ ascribed to the Jahn-Teller effect ${ }^{42}$. There have been objections to a multistep process in which the r.d.s. is the approximately diffusion-controlled loss of water ${ }^{41}$. Some preference has been shown, therefore, for an associative mechanism with nucleophilic attack on the labile $\mathrm{H}_{2} \mathrm{O}$. The fairly constant ratio for $k_{\mathrm{Cu}} / k_{\mathrm{Ni}}$ in a large number of systems does suggest, however, that the Eigen mechanism may hold for these. Similar values for $K_{0}$, for $\mathrm{Ni}^{2+}$ and $\mathrm{Cu}^{2+}$ outer-sphere complexing with a particular ligand, would then lead to the observed constant ratio.

\section{COMPLEXING WITH MULTIDENTATE LIGANDS}

Consider the ion-pair mechanism applied to reaction of $\mathrm{Ni}^{2+}$ with a bidentate ligand $\mathrm{L}-\mathrm{L}$ :

$$
\begin{aligned}
& \left(\mathrm{H}_{2} \mathrm{O}\right)_{6} \mathrm{Ni}^{2+}+\mathrm{L}-\mathrm{L} \rightleftarrows\left(\mathrm{H}_{2} \mathrm{O}\right)_{5} \mathrm{Ni}\left(\mathrm{H}_{2} \mathrm{O}\right) \mathrm{L}-\mathrm{L} \quad K_{0} \\
& \left(\mathrm{H}_{2} \mathrm{O}\right)_{5} \mathrm{Ni}\left(\mathrm{H}_{2} \mathrm{O}\right) \mathrm{L}-\mathrm{L} \rightleftarrows\left(\mathrm{H}_{2} \mathrm{O}\right)_{5} \mathrm{Ni}-\mathrm{L}-\mathrm{L}+\mathrm{H}_{2} \mathrm{O} \quad k_{2}, k_{-2}, K_{2} \\
& \left(\mathrm{H}_{2} \mathrm{O}\right)_{5} \mathrm{Ni}-\mathrm{L}-\mathrm{L} \rightleftarrows\left(\mathrm{H}_{2} \mathrm{O}\right)_{4} \mathrm{Ni}{ }_{\mathrm{L}}^{L}{ }_{1}^{\mathrm{L}}+\mathrm{H}_{2} \mathrm{O} \quad k_{3}, k_{-3}, K_{3} \\
& k_{\mathrm{f}}=K_{0} k_{2} k_{3} /\left(k_{-2}+k_{3}\right)
\end{aligned}
$$

It is apparent that the ratio $k_{3} / k_{-2}$ will dominate the kinetics of chelation. If $k_{3} \gg k_{-2}$, then $k_{\mathrm{f}}=K_{0} k_{2}$, and the circumstances when this condition will, and will not, pertain have been discussed ${ }^{6}$. The data in Table 4 illustrate the former situation.

It might have been thought that as the ligand increases in complexity and dentate character, the simplicity of kinetic pattern encountered with unidentate and many bidentate ligands might disappear. However, for ligands which have been examined, this does not appear to be the case. The rate constants for reaction of EDTAH ${ }^{3-}$ with $\mathrm{Co}^{2+}, \mathrm{Ni}^{2+}, \mathrm{Cu}^{2+}, \mathrm{Zn}^{2+}$ and

\begin{tabular}{|c|c|c|}
\hline Entering ligand & $\mathrm{Ni}\left(\mathrm{H}_{2} \mathrm{O}\right)_{6}^{2+}$ & $\mathrm{Ni}\left[\mathrm{N}\left(\mathrm{CH}_{2} \mathrm{COO}\right)_{3}\right]\left(\mathrm{H}_{2} \mathrm{O}\right)_{2}^{-}$ \\
\hline $\mathrm{H}_{2} \mathrm{O}$ & $3.0 \times 10^{4}+$ & - \\
\hline $\mathrm{NH}_{3}$ & $5.0 \times 10^{3}$ & $4.6 \times 10^{3}$ \\
\hline & $\approx 4 \times 10^{3}$ & - \\
\hline & $1.5 \times 10^{3}$ & $2.4 \times 10^{3}$ \\
\hline & $1.4 \times 10^{3}$ & $2.1 \times 10^{3}$ \\
\hline
\end{tabular}
$\mathrm{Cd}^{2+}$ can all be accommodated by the expression $k=K_{0} k_{0}$, with $K_{0}=10-20 \mathrm{M}^{-1}$ (Ref. 43). With these and a number of other ligands, the

Table 4. Rate constants $\left(k_{\mathrm{f}}\right)$ for the formation of nickel complexes at $25^{\circ} \mathrm{C}$

$+s^{-1}$, all others in $\mathrm{m}^{-1} \mathrm{~s}^{-1}$ 


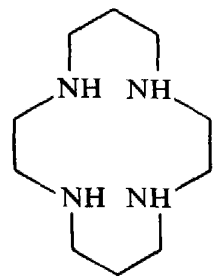

(XI)<smiles>CC1CC(C)(C)NCCNC(C)CC(C)(C)NCCN1</smiles>

(XII)

first step of chelation is rate determining and triggers a rapid sequence of ring closures.

There are some ligands, however, whose structure precludes easy in toto attachment to the metal ion and whose rate constants for metal interaction are therefore unusually low. The macrocycles, cyclam (XI) and teta (XII) (reacting as the diprotonated forms), complex very slowly with $\mathrm{Ni}^{2+}$ and $\mathrm{Cu}^{2+}$ respectively ${ }^{44,45}$. In fact, there is a blue intermediate in the reaction of $\mathrm{Cu}^{2+}$ with teta which is believed to be a complex in which only two nitrogens are attached to the copper. This intermediate slowly converts to the final stable purple product ${ }^{45}$.

Table 5. Rate constants for reaction of $\mathrm{Ni}($ cis,cis-tach $)\left(\mathrm{H}_{2} \mathrm{O}\right)_{3}^{2+}$ at $25^{\circ} \mathrm{C}$

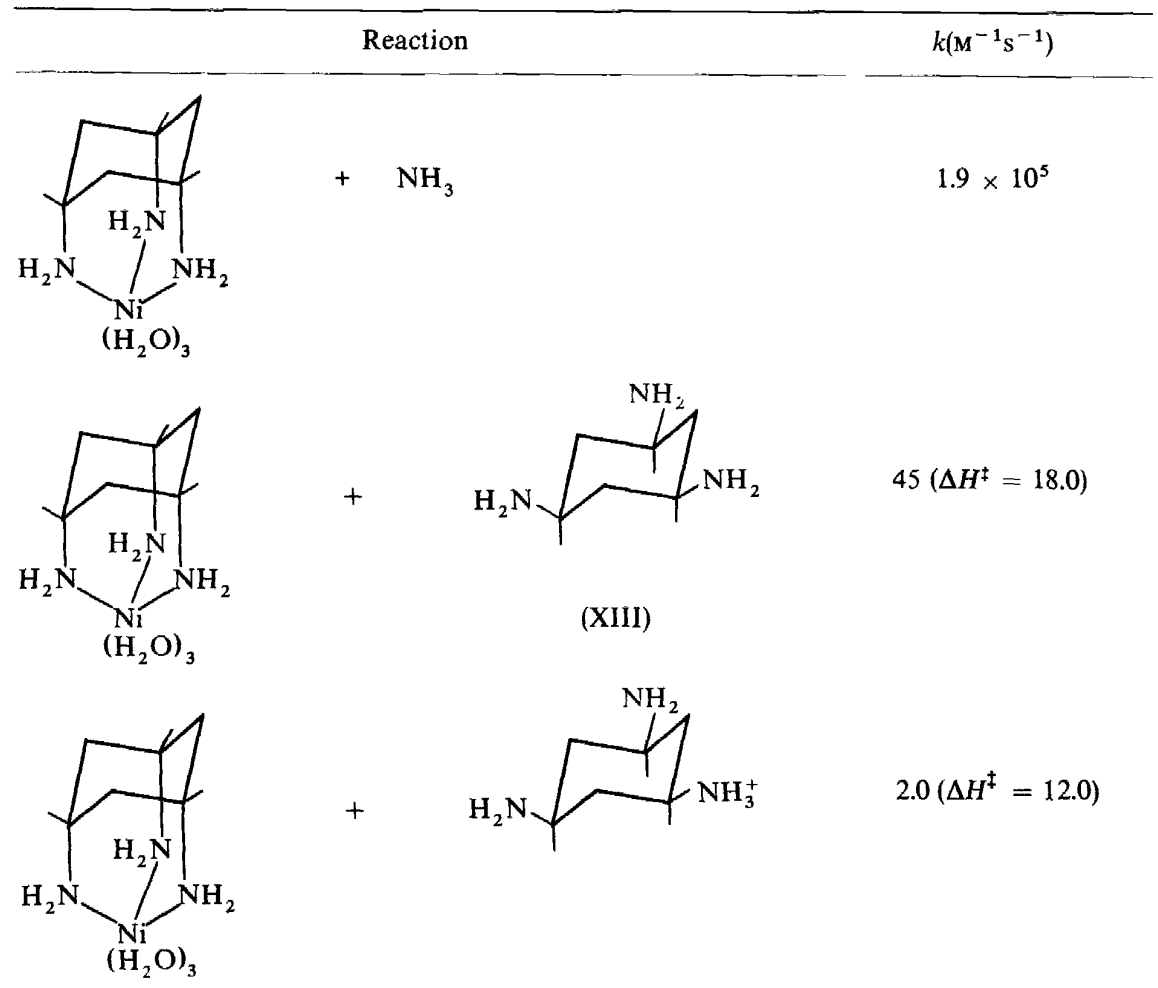




\section{R. G. WILKINS}

The $\mathrm{NH}_{2}$ groups in cis,cis-tach (XIII) are normally equatorial in the free ligand. They have to rotate into axial ring positions so as to occupy the trigonal face of an octahedral complex, when associating with a metal ion. The resulting complex is quite stable. Because of the different conformational requirements of free and complexed ligand, both the dissociation ${ }^{46}$ and the formation $^{47}$ of the nickel complex, $\mathrm{Ni}($ cis,cis-tach $)\left(\mathrm{H}_{2} \mathrm{O}\right)_{3}^{2+}$, are orders of magnitude slower than is normal for nickel. Activation parameters for the reaction of $\mathrm{Ni}$ (cis, cis-tach) $\left(\mathrm{H}_{2} \mathrm{O}\right)_{3}^{2+}$ with $\mathrm{NH}_{3}{ }^{48}$ compared with cis, cis-tach (both unprotonated and monoprotonated forms) are shown in Table 5. 'Normal' reactivity of the ligand with $\mathrm{NH}_{2}$ in axial conformation (a) combined with a relatively small concentration $(\approx 0.1$ per cent) compared with the normal conformation (e) would lead to the low rate constant.

$$
\mathrm{e} \rightleftharpoons \mathrm{a} \stackrel{\mathrm{Ni}^{\mathrm{il}}}{\rightarrow} \text { products }
$$

\section{METALLOENZYMES}

These are the complicated metal complexes referred to in the lecture title. Investigations in the area of metalloenzymes have increased substantially in the past decade. This has arisen mainly as a result of the availability of instruments to probe the metal centre through c.d., e.s.r., and n.m.r. techniques and the development of the background theory for the understanding of the results ${ }^{49,50}$.

A number of metalloenzymes containing a variety of metal ions have now been characterized. A metal centre which is invariably at or near the active site is a useful marker for investigating the function and mechanism of such enzymes. Removal of the metal ion leads to the inactive apoenzyme. In a handful of cases, activity can be restored by addition of the native or even some other metal ion. Meaningful and useful comparisons have been made of the spectral and thermodynamic features of metalloproteins with those of simpler metal complexes ${ }^{49,51-53}$. It should be as fruitful ${ }^{50}$ to compare their mechanistic behaviour, with respect to metal ion or ligand replacement reactions, with metal complex systems, about which we know (or think we know) a good deal ${ }^{2,3}$. Surprises should be expected -indeed, hoped for.

Carbonic anhydrase has occupied our attention for two years. It is an excellent beginner's enzyme. It is commercially available and remarkably stable in solution ${ }^{54}$. Some characteristics of particular interest to the coordination chemist are indicated in Table 6. The immediate environment of the zinc is indicated in Figure $2^{57}$. Only zinc(II) or cobalt(II) ions added to bovine or human apocarbonic anhydrase restore its ability to catalyse the

Table 6. Some characteristics of carbonic anhydrase

1. M.Wt. $\approx 30000$ and 260 amino acid residues catalysing hydration of $\mathrm{CO}_{2}$ and other substrates

2. $\mathrm{Zn}$ is near the centre of molecule at base of a crevice. It is coordinated by 3 imidazoles from histidyl residues and (probably) $\mathrm{H}_{2} \mathrm{O}$ in distorted tetrahedron ${ }^{57}$.

3. $\mathrm{Zn}$ can be replaced by a number of other metals (via apoenzyme). The $\mathrm{Co}^{\text {II }}$ haloenzyme is active and has strong visible bands ${ }^{53}$

4. $\mathrm{Zn}^{\mathrm{II}}$ and $\mathrm{Co}^{\mathrm{II}}$ forms interact strongly with certain sulphonamides and anions 


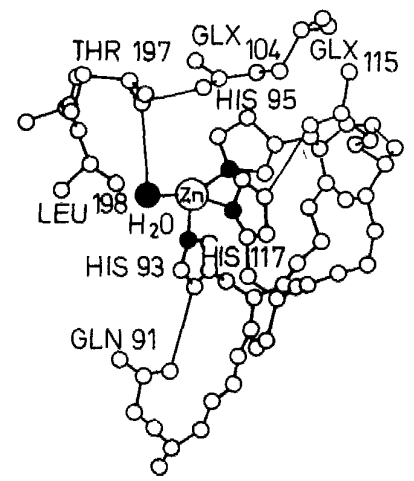

Figure 2. Environment of $\mathrm{Zn}$ in human carbonic anhydrase $\mathrm{C}^{57}$

$\mathrm{CO}_{2}+\mathrm{H}_{2} \mathrm{O} \rightleftarrows \mathrm{H}_{2} \mathrm{CO}_{3}$ equilibrium (its biological function) ${ }^{55}$ as well as display esterase activity ${ }^{56}$. The addition of nickel(II) ions to apocarbonic anhydrase does not restore activity, although simple experiments indicate that the nickel has located near or at the position usually occupied by zinc ${ }^{56}$. With this short background in mind, we consider two aspects of substitution reactions of carbonic anhydrase and metallo derivatives:

(a) Interaction of ligands with the metal centre of the enzyme.

(b) Kinetics of interaction of the apoenzyme with metal complex ions, including the simple aquated species.

\section{(a) Ligand replacement reactions in carbonic anhydrase}

Aromatic sulphonamides, $\mathrm{RSO}_{2} \mathrm{NH}_{2}$, act as strong inhibitors of carbonic anhydrase action ${ }^{54,58}$. They accomplish this by functioning as powerful ligands with high-affinity constants in which the sulphonamide centre (probably as $\mathrm{SO}_{2} \mathrm{NH}^{-}$) complexes with the metal and the unsaturated ring interacts with a hydrophobic portion of the protein near to the zinc ${ }^{57,59}$. A type of chelate structure results (Figure 3, S-S represents the sulphonamide).

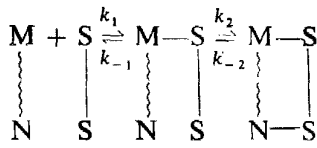

$$
\begin{aligned}
& k=\frac{k_{1} k_{2}}{\left(k_{-1}+k_{2}\right)}
\end{aligned}
$$

Figure 3. Schematic representation of enzyme-sulphonamide interaction

The kinetics of complex formation between carbonic anhydrase (zinc and cobalt haloenzymes) and sulphonamides have been investigated indirectly from inhibition behaviour ${ }^{60,61}$, and directly by stopped-flow with fluorescence $^{62}$ and spectral ${ }^{63,64}$ monitoring. A profile for the observed second-order rate constants $v$. $\mathrm{pH}$ is shown in Figure 4 for the interaction of $p$-(salicyl-5azo) benzenesulphonamide (XIV) with $\mathrm{Zn}$ isoenzyme $\mathrm{C}^{62}$. 


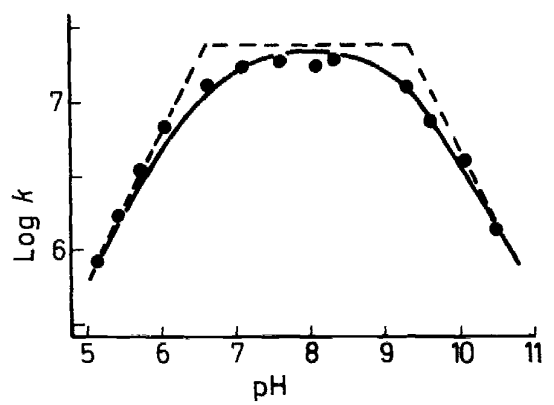

Figure 4. Association rate constant-pH profile for interaction of $\mathrm{Zn}$ isoenzyme $\mathrm{C}$ and $p$-(salicyl-5-azo)benzenesulphonamide ${ }^{62}$

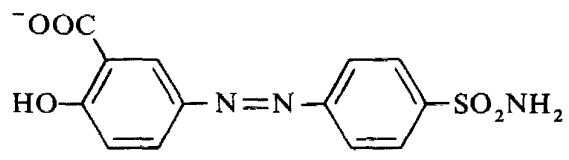

(XIV)

Both the carbonic anhydrases and the sulphonamides exist in acidic and basic forms ( $\mathrm{pKs}$ in the region of 7 and, usually, 9.5 respectively). The observed rate constant $k$ and the $\mathrm{pH}$ profile can thus be interpreted in terms of a reaction of an acidic form of enzyme, $\mathrm{CA} . \mathrm{H}^{+}$, with the basic sulphonamide, $\mathrm{RSO}_{2} \mathrm{NH}^{-}$, or vice versa $\left(\mathrm{CA}+\mathrm{RSO}_{2} \mathrm{NH}_{2}\right)$ and they are impossible to distinguish kinetically.

or

$$
\begin{array}{ccr}
\mathrm{CA}+\mathrm{H}^{+} \rightleftharpoons \mathrm{CA} \cdot \mathrm{H}^{+} & K_{\mathrm{E}} & \\
\mathrm{RSO}_{2} \mathrm{NH}^{-}+\mathrm{H}^{+} \rightleftharpoons \mathrm{RSO}_{2} \mathrm{NH}_{2} & K_{\mathrm{S}} & \\
\mathrm{CA} \cdot \mathrm{H}^{+}+\mathrm{RSO}_{2} \mathrm{NH}^{-} \rightarrow \text { inhibitor complex } & k_{1} & \text { Scheme 1 } \\
\mathrm{CA}+\mathrm{RSO}_{2} \mathrm{NH}_{2} \rightarrow \text { inhibitor complex } & k_{2} & \text { Scheme 2 }
\end{array}
$$

or

$$
\begin{array}{r}
k=\frac{K_{\mathrm{S}}}{K_{\mathrm{E}}} \times \frac{k_{1}}{\left(1+K_{\mathrm{S}} /\left[\mathrm{H}^{+}\right]\right)\left(1+\left[\mathrm{H}^{+}\right] / K_{\mathrm{E}}\right)} \\
k=\frac{k_{2}}{\left(1+K_{\mathrm{S}} /\left[\mathrm{H}^{+}\right]\right)\left(1+\left[\mathrm{H}^{+}\right] / K_{\mathrm{E}}\right)}
\end{array}
$$

This is a particularly vexing problem in complex ion kinetics, of which the $\mathrm{Fe}^{\mathrm{III}}$ interaction with basic ligands is now a classic example ${ }^{65}$. The ambiguity may be resolvable, as in the latter case, on the grounds of plausibility of the derived rate constants $k_{1}$ or $k_{2}$ on the basis of the two schemes. Estimated values for these rate constants for a number of sulphonamides and carbonic anhydrases are contained in Table 7. Some rate constants at specific $\mathrm{pH}$ for other sulphonamides are also available ${ }^{58,62}$.

Scheme 1 has been favoured ${ }^{60,61,63}$. The small range of associated formation rate constants for a variety of sulphonamides is reminiscent of the behaviour of $\mathrm{Zn}^{2+}$ with simpler ligands and the Eigen mechanism. On the basis of Scheme 1, however, the rate constant for reaction of the acid form of 


\section{SUBSTITUTION PROCESSES IN METAL COMPLEXES}

Table 7. Rate constants at $25^{\circ} \mathrm{C}$ for interaction of carbonic anhydrase with some sulphonamides, $\mathrm{RSO}_{2} \mathrm{NH}_{2}$

\begin{tabular}{|c|c|c|c|c|c|c|}
\hline $\mathbf{R}$ & Enzyme & $k_{1}$ & $k_{2}$ & $k_{\mathrm{r}}$ & Method & Ref. \\
\hline & Human & & & & & \\
\hline$p$-salicyl-5-azoC ${ }_{6} \mathrm{H}_{4}$ & C & $1.1 \times 10^{10}$ & $2.2 \times 10^{7}$ & 0.036 & 1 & 62 \\
\hline$p-\mathrm{NO}_{2} \mathrm{C}_{6} \mathrm{H}_{4}$ & $\mathrm{C}$ & $7.5 \times 10^{8}$ & $1.5 \times 10^{6}$ & 0.049 & 1 & 62 \\
\hline & $\mathrm{CoC}$ & $9.0 \times 10^{8}$ & $1.8 \times 10^{6}$ & 0.082 & 1 & 62 \\
\hline $4-\mathrm{OH}, 3-\mathrm{NO}_{2} \mathrm{C}_{6} \mathrm{H}_{3}$ & $\begin{array}{c}\mathrm{B} \\
\text { Bovine }\end{array}$ & $4.5 \times 10^{8}$ & $1.1 \times 10^{5}$ & - & 2 & 63 \\
\hline & $A$ and $B$ & $2.2 \times 10^{8}$ & $5.5 \times 10^{4}$ & 0.14 & 2 & 63 \\
\hline $\mathrm{C}_{6} \mathrm{H}_{5}$ & B & $2.8 \times 10^{8}$ & $3.5 \times 10^{5}$ & 0.21 & 3 & 60 \\
\hline$\underset{\mathrm{O}}{\mathrm{CH}_{3} \mathrm{CNH}-\mathrm{C}}-\mathrm{S}$ - & $\begin{array}{c}\mathrm{B} \\
\mathrm{CoB}\end{array}$ & $\begin{array}{l}2.6 \times 10^{7} \\
2.4 \times 10^{7}\end{array}$ & $\begin{array}{l}2.6 \times 10^{7} \\
2.4 \times 10^{7}\end{array}$ & $\begin{array}{l}0.10 \\
0.05\end{array}$ & $\begin{array}{l}3 \\
3\end{array}$ & $\begin{array}{c}60,61 \\
61\end{array}$ \\
\hline$p-\mathrm{CH}_{3} \mathrm{C}_{6} \mathrm{H}_{4}$ & $\mathrm{Co}(\mathrm{A}$ and $\mathrm{B})$ & $2.4 \times 10^{8}$ & $2.4 \times 10^{5}$ & - & 2 & 64 \\
\hline
\end{tabular}

1 stopped-flow, fluorescence

2 stopped-flow, spectral

3 inhibition of enzyme hydrolytic activity

bovine carbonic anhydrase $\mathrm{C}$ with de-ionized $p$-(salicyl-5-azo)benzenesulphonamide appears to exceed that expected for a diffusion-controlled reaction and so, for this reaction at least, the alternative deprotonated enzyme reacting with the sulphonamide (Scheme $2, k_{2}=2.2 \times 10^{7}$ ) is preferred $^{62}$. However, this sulphonamide is somewhat unique, having a negative group and an abnormally high formation constant. Further, if the acid-base equilibrium involving the enzyme is a coordinated $\mathrm{H}_{2} \mathrm{O}-\mathrm{OH}^{-}$ pair, as seems likely, then one has the unusual situation of an hydroxy ligand being preferentially displaced over a coordinated water ${ }^{66}$. Scheme 2 leads to a wider range of values of $k_{2}$ but this observation can be accommodated, as with the interaction of bidentate ligands with simpler metal ions, by the scheme shown in Figure 3. The first coordination step may involve the sulphonamide residue ${ }^{58}$ and/or the aromatic-hydrophobic pocket interactions ${ }^{62}$. The slowness of the $\mathrm{pH}$-independent dissociation (relatively small values for $k_{\mathrm{r}}$ in Table 7 compared with those of Table 8) and the high thermo-

Table 8. Rate constants at $25^{\circ} \mathrm{C}$ for interaction of human $\mathrm{C}$ carbonic anhydrase with ligands

\begin{tabular}{llllr}
\hline \multicolumn{1}{c}{ Ligand } & \multicolumn{1}{c}{$k_{\mathrm{r}}\left(\mathrm{M}^{-1} \mathrm{~s}^{-1}\right)$} & \multicolumn{1}{c}{$k_{\mathrm{r}}\left(\mathrm{s}^{-1}\right)$} & Method & Ref. \\
\cline { 1 - 1 } $\mathrm{HCOO}^{-}$ & $3.9 \times 10^{8}$ & $6.0 \times 10^{4}$ & 1 & 67 \\
$\mathrm{CH}_{2} \mathrm{FCOO}^{-}$ & $2.2 \times 10^{8}$ & $2.0 \times 10^{5}$ & 1 & 67 \\
$\mathrm{CHF}_{2} \mathrm{COO}^{-}$ & $1.9 \times 10^{8}$ & $1.0 \times 10^{5}$ & 1 & 67 \\
$\mathrm{CF}_{3} \mathrm{COO}^{-}$ & $2.0 \times 10^{8}$ & $1.5 \times 10^{5}$ & 1 & 67 \\
$\mathrm{CN}^{-}$ & $>3 \times 10^{9}$ & $>10^{2}$ & 2 & 68 \\
$\mathrm{CNO}^{-}$ & $8.0 \times 10^{6} \dagger$ & $4.0 \times 10^{2}$ & 2 & 64 \\
$p-\mathrm{NBSO}_{2} \mathrm{NH}^{-}$ & $7.5 \times 10^{8}$ & $4.9 \times 10^{-2}$ & 3 & 62 \\
$p-\mathrm{NBSO}_{2} \mathrm{NH}_{2}$ & $1.5 \times 10^{6} \ddagger$ & $4.9 \times 10^{-2}$ & 3 & 62 \\
\hline
\end{tabular}

$\dagger$ Bovine (A and B)

$\ddagger$ With basic form of enzyme

1 n.m.r.

2 dissociation rate constant from sulphonamide scavenging experiments by stopped-flow

3 directly by stopped-flow with fluorescent monitoring 


\section{R. G. WILKINS}

dynamic stability of the enzyme-sulphonamide adducts also resides in the 'chelate' nature of the interaction ${ }^{58,62}$.

What then about the interaction of simpler unidentate ligands with carbonic anhydrase? Investigation of the kinetics of interaction with a ligand not involved in an acid-base equilibrium in the $\mathrm{pH} \approx 7$ region will delineate the reactive form of the enzyme. The forward and reverse rate constants for reaction of a number of unidentate ligands and their method of study are contained in Table 8 . The data are consistent with the ligands interacting with the acid form of the enzyme ${ }^{67}$. Anion association is very fast and difficult to measure directly by flow methods $64,68,69$. Resort has been to n.m.r. line broadening techniques ${ }^{67}$ or from competition studies using sulphonamides as competitors ${ }^{64,68}$.

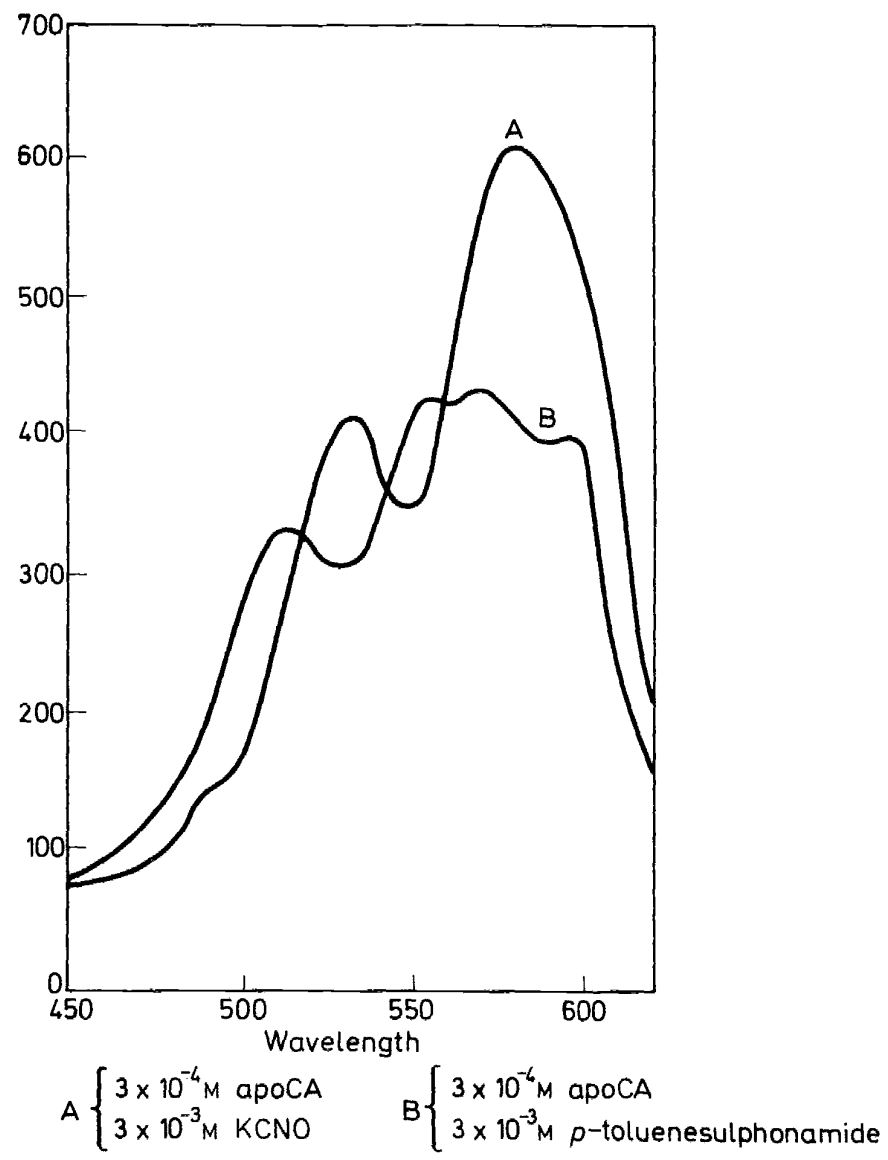

Figure 5. Spectra of Co carbonic anhydrase adducts with $\mathrm{CNO}^{-}$and $p$-toluenesulphonamide at $\mathrm{pH} 7.5$

In an application of the latter, we have used spectral stopped-flow to study the reaction of $\mathrm{Co}$-carbonic anhydrase- $\mathrm{CNO}^{-}$complex with $p$ toluenesulphonamide ${ }^{64}$. The spectral changes which accompany ligand 


\section{SUBSTITUTION PROCESSES IN METAL COMPLEXES}

interaction with Co-carbonic anhydrase ${ }^{70}$ are extremely useful for monitoring the reaction (Figure 5). For the reaction scheme:

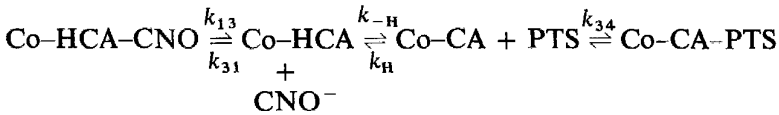

$$
\begin{aligned}
& \text { Rate }=k_{\text {obsd }}[\mathrm{COHCA}-\mathrm{CNO}] \\
& \frac{1}{k_{\mathrm{obsd}}\left[\mathrm{CNO}^{-}\right]}=\frac{1}{\left[\mathrm{CNO}^{-}\right] k_{13}}+\frac{k_{31}}{k_{13} k_{-\mathrm{H}}}+\frac{k_{31} k_{\mathrm{H}}[\mathrm{H}]}{k_{13} k_{34} k_{-\mathrm{H}}[\mathrm{PTS}]}
\end{aligned}
$$

The appropriate linear plot at $\mathrm{pH}=7.5$ is shown in Figure 6. From this, values for the formation and dissociation rate constants for the cyanate complex are obtained. That for the formation of the sulphonamide complex is in very good agreement with that obtained directly. We can take the analysis further by carrying out measurements over a $\mathrm{pH}$ range. From the plot in Figure 7, a value for $k_{31} k_{\mathrm{H}} / k_{13} k_{34} k_{-\mathrm{H}}$ can be obtained and this, with the intercept of Figure 6, leads to values for $k_{-\mathrm{H}}$ and $k_{\mathrm{H}}$. The latter appears to be just a little high for a diffusion-controlled acid-base reaction, but not unreasonable.

The association rate constants are similar for anion and sulphonamide reactions with enzyme and the greater stability of the sulphonamide complexes resides in a much lower dissociation rate constant, a not unfamiliar occurrence ${ }^{6}$.

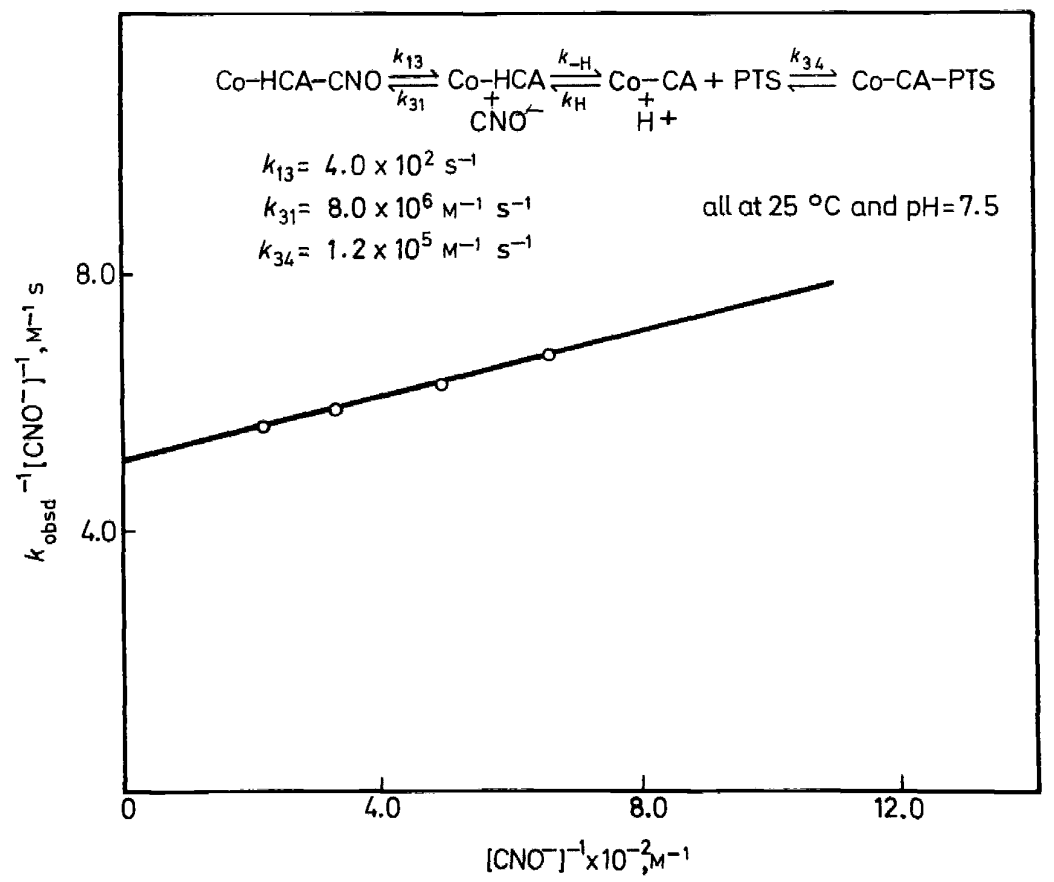

Figure 6. Plot of $k_{\mathrm{obsd}}^{-1}\left[\mathrm{CNO}^{-}\right]^{-1} v$. $\left[\mathrm{CNO}^{-}\right]^{-1} \times 10^{-2}$ for reaction of Co-carbonic anhydrase $\mathrm{CNO}^{-}$adduct at constant [PTS] 


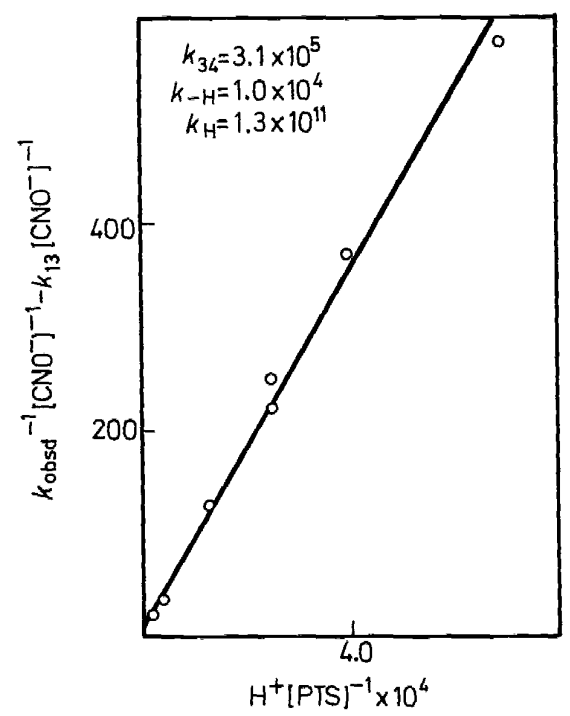

Figure 7. Plot of $k_{\mathrm{obsd}}^{-1}\left[\mathrm{CNO}^{-}\right]^{-1}-k_{13}^{-1}\left[\mathrm{CNO}^{-}\right]^{-1} v \cdot \mathrm{H}^{+}[\mathrm{PTS}]^{-1} \times 10^{4}$ for reaction of Cocarbonic anhydrase $-\mathrm{CNO}^{-}$adduct

If anion replaces coordinated water in the enzyme, for which there is a certain amount of evidence ${ }^{71}$, then the marked lability of the system resembles that of simpler tetrahedral cobalt complexes (Table 9) ${ }^{72}$. If the imidazole bonded to $\mathrm{Co}$ in the enzyme can be likened to that in $\mathrm{Co}(\mathrm{NCS})_{3} \mathrm{H}_{2} \mathrm{O}^{-}$, the parallel in rate behaviour is quite close. Mildvan ${ }^{50}$ has also pointed out a number of cases where the rates of ligand substitution are as high for simple model systems as for metalloenzymes.

Table 9. Rates of exchange of tetrahedral $\mathrm{Co}^{\mathrm{II}}$ complexes from n.m.r. ${ }^{72}$

\begin{tabular}{ll}
\hline \multicolumn{1}{c}{ Complex } & $k_{\mathrm{H}_{2} \mathrm{O}}\left(\mathrm{s}^{-1}\right)$ \\
\hline $\mathrm{Co}\left(\mathrm{NCS}_{2}\left(\mathrm{H}_{2} \mathrm{O}\right)_{2}\right.$ & $2-4 \times 10^{8}$ \\
$\mathrm{Co}\left(\mathrm{NCS}_{3}\left(\mathrm{H}_{2} \mathrm{O}\right)^{-}\right.$ & $>5 \times 10^{8}$ \\
$\mathrm{CoCl}\left(\mathrm{H}_{2} \mathrm{O}\right)_{2}$ & $>5 \times 10^{7}$ \\
$\mathrm{CoCl}_{3}\left(\mathrm{H}_{2} \mathrm{O}\right)^{-}$ & $>5 \times 10^{7}$ \\
\hline
\end{tabular}

(b) Interaction of metal ions and complexes with apocarbonic anhydrase

There appears to have been only one published study of the kinetics of enzyme regeneration from apoenzyme ${ }^{73}$. This was concerned with the interaction of zinc ion with bovine apocarbonic anhydrase- $\mathrm{B}^{73}$. The reaction was studied in detail, a number of methods were used to follow enzyme regeneration, with consistent results, and the data were compared with those for interaction of zinc ion with simpler ligands of the bipyridine or phenanthroline type ${ }^{74}$ (Table 10).

Bovine and human apocarbonic anhydrase react with a number of metal 
Table 10. Activation parameters at $25^{\circ} \mathrm{C}$ for reaction of bivalent transition metal ions with phenanthroline compared with bovine apocarbonic anhydrase (ACA)

\begin{tabular}{|c|c|c|c|c|}
\hline \multicolumn{2}{|c|}{$k\left(\mathrm{M}^{-1} \mathrm{~s}^{-1}\right)$} & $\Delta H^{\ddagger}$ & $\Delta S^{\ddagger}$ & Ref. \\
\hline $\begin{array}{r}\mathrm{Mn}^{2+}+\text { phen } \\
+\mathrm{ACA}\end{array}$ & $\begin{array}{l}2.5 \times 10^{5} \\
2.4(\mathrm{pH}=6.5)\end{array}$ & - & - & $\begin{array}{l}74 \\
64\end{array}$ \\
\hline $\begin{aligned} \mathrm{Co}^{2+} & + \text { phen } \\
& +\mathrm{ACA}\end{aligned}$ & $\begin{array}{l}2.0 \times 10^{5} \\
4.0(2.0)\end{array}$ & $\begin{array}{l}11 \\
24\end{array}$ & $\begin{array}{l}+2 \\
+32\end{array}$ & $\begin{array}{l}74 \\
64,75\end{array}$ \\
\hline $\begin{aligned} \mathrm{Ni}^{2+} & + \text { phen } \\
& + \text { ACA }\end{aligned}$ & $\begin{array}{l}2.5 \times 10^{3} \\
5.0\end{array}$ & 13 & +2 & $\begin{array}{l}74 \\
64\end{array}$ \\
\hline $\begin{aligned} \mathrm{Cu}^{2+} & + \text { phen } \\
& +\mathrm{ACA}\end{aligned}$ & $\begin{array}{l}6.4 \times 10^{7} \\
6.0 \times 10^{4}\end{array}$ & $\begin{array}{r}5 \\
21\end{array}$ & $\begin{array}{l}-6 \\
+34\end{array}$ & $\begin{array}{l}30 \\
75\end{array}$ \\
\hline $\begin{aligned} \mathrm{Zn}^{2+} & + \text { phen } \\
& + \text { ACA }\end{aligned}$ & $\begin{array}{l}6.0 \times 10^{6} \\
2.0 \times 10^{3}\end{array}$ & $\begin{array}{r}6 \\
20\end{array}$ & $\begin{array}{l}-9 \\
+28\end{array}$ & $\begin{array}{l}74 \\
73\end{array}$ \\
\hline
\end{tabular}

ions to form the haloenzyme ${ }^{55,56}$. The second-order rate constants for reactions of $\mathrm{Cu}^{2+}$ and $\mathrm{Co}^{2+}$ with the bovine enzyme have now also been determined by stopped-flow with fluorescence monitoring ${ }^{75}$. We have independently measured them by using the proton release attendant on metal incorporation in the apoenzyme ${ }^{64}$. The reactions are conveniently slow when $\mu \mathrm{M}$ apoenzyme and metal ion concentrations are used in conjunction with a sensitive $\mathrm{pH}$-meter. In all cases examined, the second-order rate constant is several orders of magnitude less than normally encountered with simpler systems due to a larger $\Delta H^{\ddagger}$ partly offset by larger positive $\Delta S^{\ddagger}$ values. These latter values have been ascribed to loss of water from either reactant ${ }^{73}$. Although the differences in rate behaviour appear genuine and worth commenting on, it should be emphasized that the effect of $\mathrm{pH}$ on the rate constant differs markedly from one metal to another. A very small effect of $\mathrm{pH}$ on the rate of $\mathrm{Zn}^{2+}$ interaction with apocarbonic anhydrase ${ }^{73}$ should be contrasted with the marked bell-shape rate-pH profile for $\mathrm{Ni}^{2+}$ reacting with the apoenzyme ${ }^{64}$. Until the reasons for this are sorted out and step-by-step mechanisms are known, it is premature to analyse the differences in detail. The question of the uniformly lower rate constants for reaction of apoenzymes is, however, an intriguing one. It might, in certain cases, reside in only a particular form of the metal ion (e.g. tetrahedral zinc ion) reacting with the apoenzyme. If this is in very small concentration, the observed rate constant will be reduced accordingly. Then too, we are concerned with the coordination of metal ion to a multidentate ligand site in the enzyme with an 'unusual' geometry so that attachment of one donor site to the metal ion may not be rate determining, as it often is in simpler systems. There may be a large number of coordination and de-coordination acts before fruitful chelation and final product formation. Finally, the protein environment of the metal bonding site may mean that comparisons with complex formation in non-aqueous solution are more relevant and this may be strikingly different from that in water. We have recently studied the interaction of metal complexes, ML, with the apoenzyme $\left(L^{\prime}\right)$. This process formally resembles simple ligand replacement:

$$
\mathrm{ML}+\mathrm{L}^{\prime} \rightleftharpoons \mathrm{MLL}^{\prime} \rightleftharpoons \mathrm{ML}^{\prime}+\mathrm{L}
$$




\section{R. G. WILKINS}

in which evidence for mixed complexes, MLL', participating in the ligand interchange has been obtained both indirectly and directly ${ }^{2}$. Whether ML can directly attack the metal site in the enzyme might depend on the relative size of the cleft opening leading to the active site and that of ML, but, probably more important, on the nature of the ligand L. It is known, for example, that $\mathrm{N}_{3}^{-}$and $\mathrm{SCN}^{-}$can coordinate to zinc and cobalt in carbonic anhydrase and that phenanthroline is a strong inhibitor for carboxypeptidase action (and therefore a ligand towards the zinc). Metal complexes with such ligands might therefore independently react with apoenzyme (rather than through the dissociated metal ion).

We have already found quite interesting differences in the behaviour of cobalt(II) complexes towards bovine apocarbonic anhydrase.

We have examined the interaction of bovine apocarbonic anhydrase with a number of $1: 1$ cobalt(II)-ligand complexes. The rate constants for the reactions are indicated in Table 11 . We have sufficient data to reach some tentative conclusions:

(a) Cobalt(II) complexes containing bidentate and terdentate ligands appear to reach the metal site in toto, where the ligand is released. No ternary complex involving enzyme, ligand and metal is observed spectrally.

(b) An aromatic ring may assist in the location of the cobalt(II) complex, perhaps by interaction with the hydrophobic pocket near the site.

(c) Cobalt(II) complexes containing tetradentate and higher dentate ligands react extremely slowly with apocarbonic anhydrase (probably via free

Table 11. Interaction of $1: 1 \mathrm{Co}^{\mathrm{II}}$-ligand complexes with apocarbonic anhydrase at $25^{\circ} \mathrm{C}$ and $\mathrm{pH}=7.5$

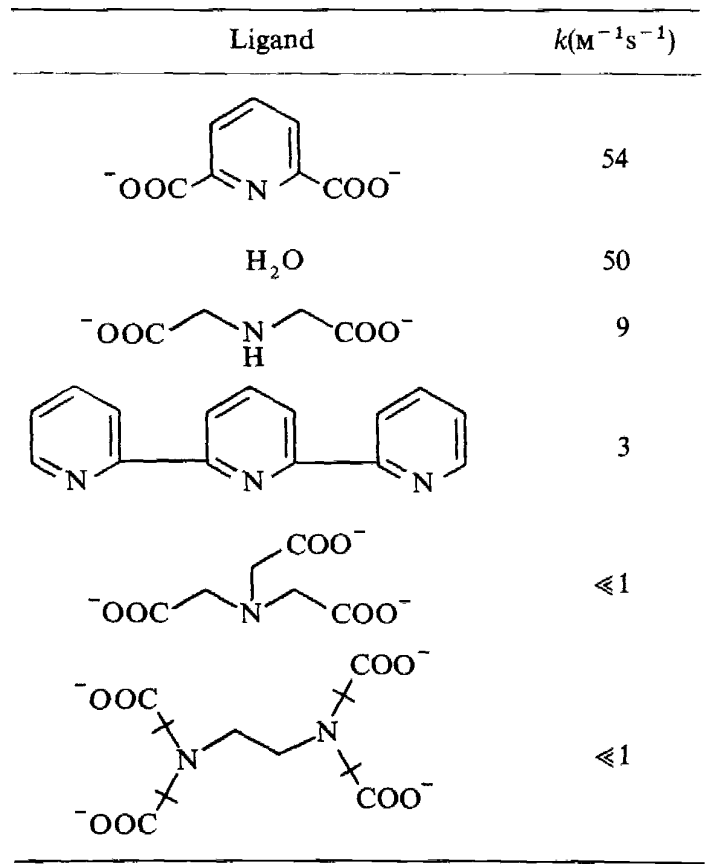


$\mathrm{Co}^{2+}$ ion). This may arise from their increased bulk or, more likely, because they contain a limited number $(<2)$ of coordinated waters which can be replaced by the imidazole ligand sites of the apoenzyme. These studies which are continuing, are related to the observations on transfer of $\mathrm{Fe}^{\mathrm{III}}$ between chelates and apotransferrin ${ }^{76}$.

\section{Summary}

Mechanistic studies of ligand and metal ion replacement in carbonic anhydrase and other metalloenzymes may help delineate the patterns of catalysis and inhibition shown by various substrates and ligands. Catalytic inhibition is believed to take place either through forming mixed complexes with the metal centre or, in certain cases, by removing the metal entirely ${ }^{49}$. Furthermore, the study of the rate- $\mathrm{pH}$ profile for ligand substitution should be helpful in characterizing the ionizing group which plays such a dominant role in the various reactions of carbonic anhydrase. Finally, these systems present an opportunity to extend our knowledge of inorganic reaction mechanisms by examining 'unique' ligands offering donor sites with unusual stereochemical relationships with one another.

\section{ACKNOWLEDGEMENT}

Our work reported in this paper has been supported by the National Science Foundation to whom we are extremely grateful. The unreported work on carbonic anhydrase has been carried out by Drs Flora $\mathrm{Ng}$ and Richard Pizer, and we extend thanks to Dr Jon Brodie for considerable help and encouragement in our initiation in this area.

\section{REFERENCES}

1 R. G. Wilkins, Nature, 167, 434 (1951).

2 F. Basolo and R. G. Pearson, Mechanisms of Inorganic Reactions, Wiley, New York (1967). The overwhelming bulk of the references postdate 1950 .

${ }^{3}$ C. H. Langford and H. B. Gray, Ligand Substitution Processes, W. A. Benjamin, New York (1966).

4 A. McAuley and J. Hill, Quart. Rev. Chem. Soc. 23, 18 (1969).

5 D. J. Hewkin and R. H. Prince, Coord. Chem. Rev. 5, 45 (1970).

${ }^{6}$ R. G. Wilkins, Accounts of Chemical Research, 3, 408 (1970).

7 K. Kustin and J. Swinehart, Prog. Inorg. Chem. 13, 107 (1970).

${ }^{8}$ D. B. Rorabacher and C. A. Melendez-Cepeda, J. Am. Chem. Soc. 93, 6071 (1971).

9 W. S. Melvin, D. B. Rablen and G. Gordon, lnorg. Chem. 11, 488 (1972).

10 J. E. Letter, Jr. and R. B. Jordan, J. Am. Chem. Soc. 93, 864 (1971).

11 T. R. Stengle and C. H. Langford, Coord. Chem. Rev. 2, 349 (1967).

12 J. P. Hunt, Coord. Chem. Rev. 7, 1 (1971).

13 L. L. Rusnak and R. B. Jordan, Inorg. Chem. 10, 2686 (1971).

14 E. B. Fleischer and M. Krishnamurthy, J. Am. Chem. Soc. 93, 3784 (1971).

15 E. B. Fleischer, S. Jacobs and L. Mestichelli, J. Am. Chem. Soc. 90, 2527 (1968).

16 M. Tsutsui, D. Ostfeld and L. M. Hoffman, J. Am. Chem. Soc. 93, 1821 (19.71).

17 J. H. Weber and D. H. Busch, Inorg. Chem. 4, 472 (1965).

18 R. G. Wilkins, R. Yelin, D. W. Margerum and D. C. Weatherburn, J. Am. Chem. Soc. 91, 4326 (1969).

19 K. J. Ivin, R. Jamison and J. J. McGarvey, J. Am. Chem. Soc. 94, 1763 (1972).

20 D. B. Rablen, H. W. Dodgen and J. P. Hunt, J. Am. Chem. Soc. 94, 1771 (1972).

21 R. Barca, J. Ellis, M. S. Tsao and W. K. Wilmarth, Inorg. Chem. 6, 243 (1967).

22 R. J. Allen and P. C. Ford, Inorg. Chem. 11, 679 (1972).

23 W. C. Randall and R. A. Alberty, Biochem. 6, 1520 (1967). 


\section{R. G. WILKINS}

24 J. E. Letter, Jr. and R. B. Jordan, Inorg. Chem. 10, 2692 (1971).

25 J. C. Cassatt, W. A. Johnson, L. M. Smith and R. G. Wilkins, J. Am. Chem. Soc. 95, 000 (1973).

${ }^{26}$ G. B. Kolski and D. W. Margerum, Inorg. Chem. 7, 2239 (1968).

7 D. N. Hague and J. Halpern, Inorg. Chem. 6, 2059 (1967).

${ }^{28}$ M. Eisenstadt, J. Chem. Phys. 51, 4421 (1969).

29 D. E. Goldsack, W. S. Eberlein and R. A. Alberty, J. Biol. Chem. 240, 2653 (1966).

${ }^{30}$ T. S. Roche and R. G. Wilkins, Chem. Commun. 1681 (1970) and unpublished results.

${ }^{31}$ K. Nakamoto, J. Phys. Chem. 64, 1420 (1960).

32 J. C. Cassatt and R. G. Wilkins, J. Am. Chem. Soc. 90, 6045 (1968).

33 S. P. Bag, Q: Fernando and H. Freiser, Inorg. Chem. 1, 887 (1962).

34 A. R. Katritzky, Chimia, 24, 134 (1970).

35 V. S. Sharma and D. L. Leussing, Inorg. Chem. 11, 138 (1972).

${ }^{36}$ L. J. Kirschenbaum and K. Kustin, J. Chem. Soc. A, 684 (1970).

37 R. E. Shepherd, G. M. Hodgson and D. W. Margerum, Inorg. Chem. 10, 989 (1971).

38 Data for this figure are obtained from a number of literature tabulations.

39 D. W. Margerum, D. B. Rorabacher and J. F. G. Clarke, Jr., Inorg. Chem. 2, 667 (1963).

40 K. Kustin, R. F. Pasternack and E. M. Weinstock, J. Am. Chem. Soc. 88, 4610 (1966).

41 R. F. Pasternack, P. R. Huber, U. M. Huber and H. Sigel, Inorg. Chem. 11, 276 (1972) and references therein.

42 M. Eigen, Ber. Bunsenges. Physik. Chem. 67, 753 (1963).

43 D. W. Margerum, P. J. Menardi and D. L. Janes, Inorg. Chem. 6, 283 (1967).

44 T. Kaden, Helv. Chim. Acta, 53, 617 (1970).

45 T. Kaden, Helv. Chim. Acta, 54, 2307 (1971).

46 R. F. Childers and R. A. D. Wentworth, Inorg. Chem. 8, 2218 (1969).

47 R. G. Wawro and R. G. Wilkins, unpublished results.

48 J. P. Jones, E. J. Billo and D. W. Margerum, J. Am. Chem. Soc. 92, 1875 (1970).

49 B. L. Vallee and W. E. C. Wacker, Metalloproteins in The Proteins, Vol. V (ed. H. Neurath) Academic Press, New York (1970); J. E. Coleman, Progress in Bio-Organic Chemistry. (eds. E. T. Kaiser and F. J. Kezdy) John Wiley and Son, New York (1972).

so A. S. Mildvan, Metals in Enzyme Catalysis in The Enzymes, 3rd ed., Vol. 2, Academic Press (1970).

51 B. L. Vallee and R. J. P. Williams, Proc. Nat. Acad. Sci. 59, 498 (1968); Chemistry in Britain, 397 (1968).

52 B. G. Malmström, Pure and Appl. Chem. 24, 393 (1970).

53 S. Lindskog, Structure and Bonding, 8, 153 (1970).

54 J. T. Edsall, The Carbonic Anhydrases of Erythrocytes, Harvey Lecture Serjes, 62, 191 (1968).

s5 S. Lindskog and B. G. Malmström, Biochem. Biophys. Research Commun. 2, 213 (1960); J. Biol. Chem. 237, 1129 (1962); E. E. Rickli and J. T. Edsall, J. Biol. Chem., 237, PC 258 (1962).

56 A. Thorslund and S. Lindskog, Eur. J. Biochem. 3, 117 (1967); J. E. Coleman, J. Biol. Chem. 242, 5212 (1967).

57 K. Fridborg, K. K. Kannan, A. Liljas, J. Lundin, B. Strandberg, R. Strandberg, B. Tilander and G. Wiren, J. Mol. Biol. 25, 505 (1967); A. Liljas, K. K. Kannan, P. C. Bergsten, I. Waara, K. Fridborg, B. Strandberg, U. Carlbom, L. Jarup, S. Lovgren and M. Petef, Nature New Biology, 235, 131 (1972).

58 J. E. Coleman, $\mathrm{CO}_{2}$ : Chemical, Biochemical and Physiological Aspects, p. 141 (eds. R. E. Forster, J. T. Edsall, A. B. Otis and F. J. W. Roughton) Washington, D.C., N.A.S.A. (1969); S. Lindskog, ibid., p. 157.

59 J. F. Hower, R. W. Henkens and D. B. Chesnut, J. Am. Chem. Soc. 93, 6665(1971) and references therein.

60 J. C. Kernohan, Biochem. Biophys. Acta, 118, 405 (1966).

61 S. Lindskog and A. Thorslund, Eur. J. Biochem. 3, 453 (1968).

62 P. W. Taylor, R. W. King and A. S. V. Bergen, Biochem. 9, 2638, 3894 (1970).

63 J. Olander and E. T. Kaiser, J. Am. Chem. Soc. 92,5758 (1970).

64 Flora $\mathrm{Ng}, \mathrm{R}$. Pizer and R. G. Wilkins, unpublished results.

65 D. Seewald and N. Sutin, Inorg. Chem. 2, 643 (1963).

66 In simple metal complexes ${ }^{2}$, and in the cobalamins ${ }^{23}$, replacement of the coordinated hydroxo group is very little favoured compared with the water group. Of course, an addition rather than a substitution at the metal centre may be involved with the enzyme.

67 P. W. Taylor, J. Feeney and A. S. V. Burgen, Biochem. 10, 3866 (1971). 


\section{SUBSTITUTION PROCESSES IN METAL COMPLEXES}

68 P. W. Taylor and A. S. V. Burgen, Biochem. 10, 3859 (1971).

69 Temperature-jump studies might be useful in measuring the rates of enzyme-anion interaction.

70 S. Lindskog, J. Biol. Chem. 238, 945 (1963); Biochem. 5, 2641 (1966); J. E. Coleman, ibid. 4, 2644 (1965).

71 K. Fabry, J. Biol. Chem. 245, 4256 (1970).

72 A. H. Zeltmann, N. A. Matwiyoff and L. O. Morgan, J. Phys. Chem. 73, 2689 (1969); A. H. Zeltmann and L. O. Morgan, Inorg. Chem. 9, 2522 (1970).

${ }^{73}$ R. W. Henkens and J. M. Sturtevant, J. Am. Chem. Soc. 90, 2669 (1968).

${ }^{74}$ R. H. Holyer, C. D. Hubbard, S. F. A. Kettle and R. G. Wilkins, Inorg. Chem. 4, 929 (1965).

75 S. A. Rudolph and J. M. Sturtevant, Biophys. Soc. Abstr. 189a (Feb. 1970); S. A. Rudolph, Ph.D. Thesis, Yale University (1971).

${ }^{76}$ G. W. Bates and J. Wernicke, J. Biol. Chem. 246, 3679 (1971), and previous papers. 